\title{
Treatment of Log Yard Runoff Impacted by Aged Logs in a Free Water Surface Constructed Wetland
}

\author{
Åsa Hedmark, ${ }^{1,2}$ Miklas Scholz, ${ }^{3, *}$ and Torbjörn Elowson ${ }^{1}$ \\ ${ }^{1}$ Swedish University of Agricultural Sciences, Department of Forest Products, Uppsala, Sweden. \\ ${ }^{2}$ Scottish Environment Protection Agency, Corporate Office, Stirling, Scotland, UK. \\ ${ }^{3}$ Institute for Infrastructure and Environment, School of Engineering, The University of Edinburgh, Edinburgh Scotland, UK.
}

Received: March 2, 2009 Accepted in revised form: September 8, 2009

\begin{abstract}
Hurricanes pose a great risk to forestry, and lead to high financial losses due to destroyed wood. For example, the hurricane "Gudrun" devastated a large part of the forests of southern Sweden in January 2005. Windthrown logs are removed from forest, temporarily stored on log yards, and frequently sprinkled with water to avoid decay. However, the subsequent runoff may cause environmental pollution. The aim of this original article is to assess the treatment of log yard runoff, which was impacted by logs of different age, in an inexpensive free water surface constructed wetland. Considering that there is commonly insufficient space for treatment wetlands, a small wetland was retrofitted into an existing ditch next to the log yard. Among other parameters, total organic carbon, total phosphorus, and total nitrogen were measured. Results show insufficient treatment of log yard runoff. The storage of aged windthrown logs led to a higher content of total phosphorus in the runoff. It is likely that the hydraulic loading rate in this wetland case study was too high, and that the concentration of oxygen in the runoff was too low for the biochemical processes in the wetland to reduce the concentrations of total phosphorus, total organic carbon, and suspended solids. It follows that a similar wetland treatment system to be designed in the future should either be made larger or supplemented by alternative further treatment solutions such as increased oxygenation or the introduction of aggregates promoting the adsorption of phosphorus.
\end{abstract}

Key words: biotechnology; log yard; macrophytes; phosphorus; runoff control; suspended solids; total organic carbon; water quality; wetland; wood degradation

\section{Introduction}

\section{Storage of logs and generation of polluted runoff}

$\mathrm{C}$

ONTAMINATED STORM RUNOFF FROM LOG YARDS is generated when precipitation comes into contact with wood, woody debris, and equipment at outdoor wood sorting, processing, and storage facilities (Woodhouse and Duff, 2004). Runoff can also be generated by application of water for dust and fire control (Orban et al., 2002). In northern Europe, Canada, and South Africa, it is also common that stored logs are sprinkled with water (Webber and Gibbs, 1996; Malan, 2004; Hildén et al., 2006). The sprinkling process protects the wood by keeping the moisture content of the wood at a high level and creating a protective water film on the wood surface. This prevents damages to the wood from rapid drying, and

*Corresponding author: Institute for Infrastructure and Environment, School of Engineering, William Rankine Building, Mayfield Road, The King's Buildings, The University of Edinburgh, Edinburgh EH9 3JL, Scotland, Uk. Phone: 0044131 6506780; Fax: 0044131 6506554; E-mail: m.scholz@ed.ac.uk limits biological attack by insects and fungi. It follows that the logs can be stored and still retain a sufficiently high quality to be used in subsequent production. There are techniques, such as climate controlled sprinkling, which can be applied to minimize the amount of sprinkling water. The sprinkling intensities can be decreased with this method by between 31 and $97 \%$ over a $24-\mathrm{h}$ period (Liukko and Elowson, 1995). A medium-sized log yard in central Sweden with a climateadapted sprinkling and nonrecirculating system uses approximately $100,000 \mathrm{~m}^{3}$ water between May and September. During this period, the amount of log yard runoff may be as high as $70,000 \mathrm{~m}^{3}$ (Jonsson, 2004).

\section{Characteristics of log yard runoff and possible treatment systems}

There are considerable differences in the characteristics of runoff from storage of wood in different studies. These differences may be due to the species of tree stored on the log yard, the proportion of the runoff that has come in contact with stored wood, and the dilution or pretreatment of the 
runoff before sampling (Hedmark and Scholz, 2008). It is also likely that the duration of time for which the wood has been stored before the samples are taken influences the concentration of pollutants in the runoff because of degradation processes in the wood (Feist et al., 1971).

A comprehensive review of the pollution content of log yards in different studies can be found in Hedmark and Scholz (2008). Despite the differences between studies, some general conclusions can be drawn from the characteristics of various runoffs. The main problem connected with pollution from log yard runoff is the high amount of organic matter that can lead to oxygen deficiencies in receiving watercourses. Some organic compounds can also be toxic to water organisms (Jonsson et al., 2006). In addition, the increased concentrations of phosphorus in log yard runoff may be high enough to cause eutrophication in the receiving watercourses (Scholz et al., 2007), and might lead to considerable loads in the large runoff volumes produced from a sprinkled log yard every year. The amount of particles in the runoff can also be relatively high (DeHoop et al., 1998). Another common characteristic of the runoff is that the concentration of nitrogen is generally relatively low compared to corresponding concentrations in natural watercourses (Scholz, 2006).

For a lot of sawmills and log yards, it is important to select a treatment method with reasonable costs for installation and maintenance. Previous studies of treatment of wood waste leachate in constructed wetlands have shown good results (Masbough et al., 2005; Tao et al., 2006a, 2006b) for organic matter, and constructed wetlands have also shown good treatment effect with respect to the removal of phosphorus in agricultural, urban and industrial waters (Braskerud, 2002 Lee et al., 2006; Scholz, 2006). Treatment in soil infiltration systems also has shown promising results for log yard runoff (Hedmark and Jonsson, 2008). Constructed treatment wetlands (Lee et al., 2006) and soil infiltration systems do not require high technical maintenance, and the amount of labor necessary to keep them operating is low. In general, these systems are less costly than conventional techniques used for the treatment of wastewater, and are viable options for wood handling operators (Hedmark and Scholz, 2008).

\section{Effects of the hurricane "Gudrun"}

Between 8 and 9 January 2005, the hurricane "Gudrun" devastated a large part of the forests of southern Sweden. Approximately $70 \mathrm{Mm}^{3}$ of timber were windthrown in just one night, equaling a mean annual felling in the whole country but impacting on less than $20 \%$ of the total forested area (Björheden, 2007). The gross value of the fallen timber was equivalent to over SEK 20,000,000,000 (Skogsstyrelsen, 2006). The hurricane was a disaster for the Swedish forest industry, and a devastating blow for a lot of private forest owners who saw their livelihoods and the hard work of previous generations swept away.

The hurricane also gave rise to logistical problems on a large scale. The insects Tomicus piniperda L. (common pine shoot beetle), Ips typographus L. (European spruce bark beetle), and Trypodendron lineatum (Olivier) (striped ambrosia beetle) pose a great risk for the forest industry (Lindelöw et al., 1992 Müller et al., 2002; Zhang and Schlyter, 2003). Because of the high risk of insect damage on standing trees due to the presence of windthrown trees, which are breeding substrates for these insects, excessive amounts of windthrown trees should be removed from the forest before July of each year (Wichmann and Ravn, 2001). Despite great efforts from the whole forestry sector, it was not possible to remove all windthrown trees from the forests during 2005. Therefore, in 2006, a lot of sawmills in southern Sweden were storing and sprinkling windthrown logs that had been left in the forest for more than a year before being transported to the corresponding storage areas. Some possible environmental consequences of this are discussed below.

\section{Aims}

The aims of this research study were to assess the following:

- Whether a relatively small free surface flow constructed wetland could be a cost-effective and successful method to reduce the concentrations of pollutants in the runoff.

- Whether contaminants leach out of the constructed wetland outside the sprinkling season.

- Whether the hurricane in 2005 led to changes in the characteristics of the runoff, when large proportions of older windthrown logs were stored at the study site.

\section{Materials and Methods}

\section{Description of the study sites}

The treatment wetland study site was a sawmill in Boxholm in the county of Östergötland located in the South of Sweden $\left(58^{\circ} 11^{\prime} \mathrm{N}, 15^{\circ} 2^{\prime} \mathrm{E}\right)$. Figure 1 indicates the layout of the site. The sawmill normally stores up to $24,000 \mathrm{~m}^{3} \operatorname{logs}$ of Picea abies (L.) Karst (Norway spruce) and Pinus sylvestris L. (Scots pine) on an asphalted log yard (Fig. 1A and B, respectively) where the logs are sprinkled with water from a nearby natural and relatively clean watercourse (Fig. 1, W). The logs have a typical range of diameters between 150 and $400 \mathrm{~mm}$ (including the bark) and are normally stored in piles of approximately $3 \mathrm{~m}$ height.

Part $C$ of the log yard (Fig. 1) is used for occasional storage of logs that are not sprinkled. The total area of the log yard is approximately $8 \mathrm{ha}$, and the sprinkled parts $\mathrm{A}$ and $\mathrm{B}$ are approximately 3.3 and $1.7 \mathrm{ha}$, respectively. The sprinkling is climate controlled, and the log yard runoff is returned to the watercourse via transport ditches and culverts, three storage ponds (Fig. 1, P1-P3) and a nonmaintained partly clogged constructed vertical subsurface flow gravel filter (Fig. 1, F). The mean annual precipitation for the area is $550 \mathrm{~mm}$, the mean annual evaporation is around $450 \mathrm{~mm}$, and the mean annual temperature is $6.1^{\circ} \mathrm{C}$ (Alexandersson et al., 1991; Brandt et al., 1994).

\section{Sampling, analysis and statistical evaluation}

The runoff from the log yard at the wetland treatment study site was investigated between 2004 and 2007. During 2004 and 2005, water samples were taken at up to 12 locations along the flow of the runoff from the log yard to the receiving watercourse (Table 1 and Fig. 1). The sampling was done to assess the possibilities of improving or replacing the existing abatement system (storage ponds and gravel filter) that did not treat the water sufficiently. Grab samples of $100 \mathrm{~mL}$ were taken at each sampling point, and the water was kept cool 


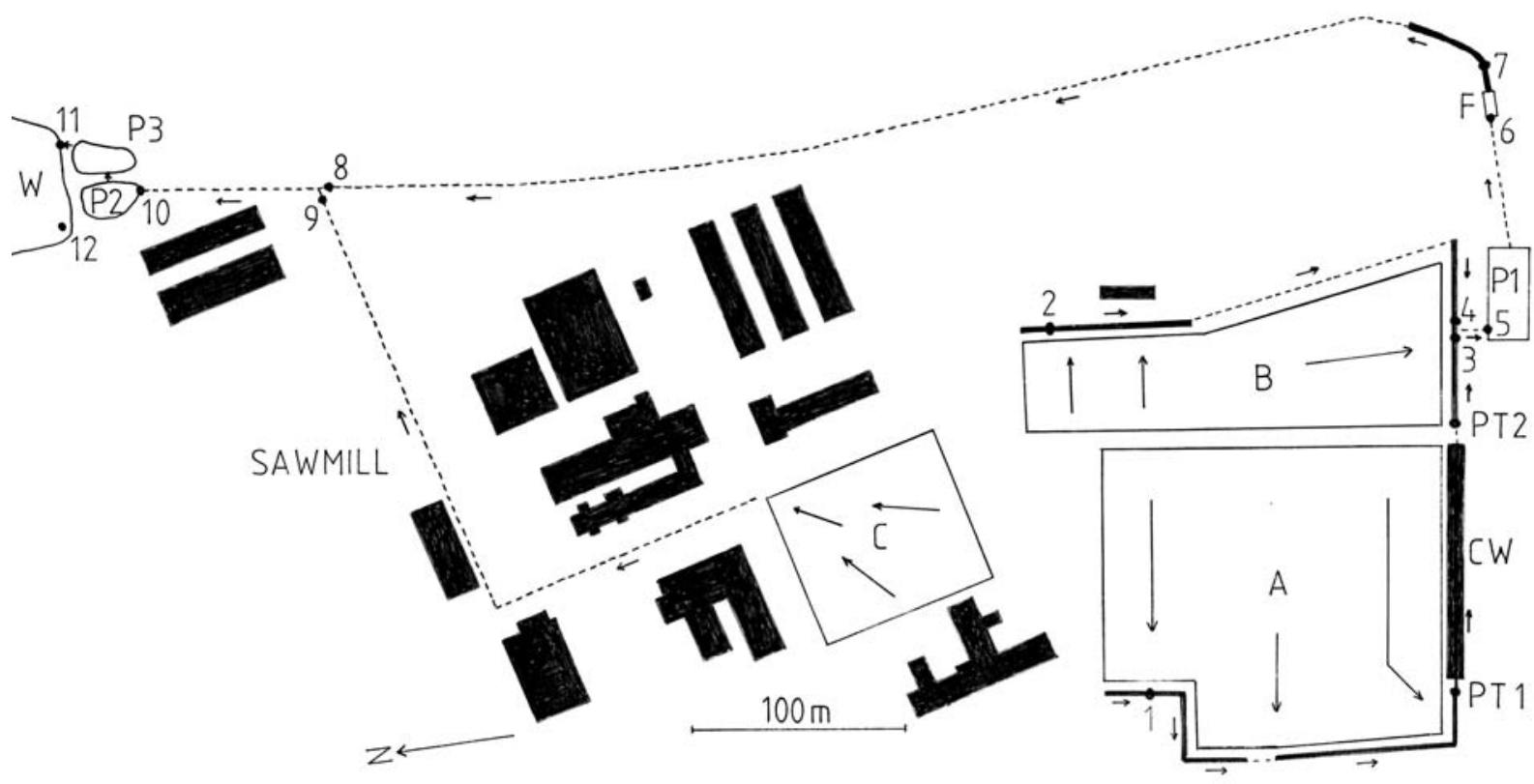

FIG. 1. Drawing of the sawmill in Boxholm, Sweden, showing the different parts $(\mathrm{A}-\mathrm{C})$ of the log yard, constructed wetland $(\mathrm{CW})$, storage ponds (P1-P3), gravel filter $(\mathrm{F})$, receiving watercourse $(\mathrm{W})$, and sampling points 1-12 (see also Table 1), PT1 and PT2.

during transport to Linköping, a city in Östergötland, where it was frozen awaiting analysis.

In autumn 2005, a constructed wetland (Fig. 1, CW) was built to improve the treatment of the log yard runoff before it was released to the watercourse (Fig. 1, W). Automatic flowproportional samplers (Isco 6712C Compact Portable Sampler, Teledyne Isco Inc., Lincoln, NE) were placed at the inlet (Fig. 1, PT1) and outlet (Fig. 1, PT2) of the constructed wetland, where the flow was led over $45^{\circ}$-V-notch weirs and measured with ultrasonic sensors (Isco 710 Ultrasonic Flow Module, Teledyne Isco Inc.).

The automatic sampling equipment was set to take $10-\mathrm{mL}$ samples for every $10 \mathrm{~m}^{3}$ of $\log$ yard runoff. Every 2 weeks, a 100-mL subsample was taken from each automatic sampler. During the intense monitoring of the wetland between late August and early October 2007, the automatic samplers were equipped with a 12-bottle sampling set each for sequential sampling, and 100-mL subsamples were subsequently taken from each bottle.

The analyses of the water samples were performed by the Soil Science Laboratory at the Swedish University of Agricultural Sciences in Umeå, Västerbotten, Sweden. Total organic carbon (TOC) and dissolved organic carbon (DOC) were analyzed using combustion oxidation (Shimadzu TOC-5000, Shimadzu, Kyoto, Japan). Total phosphorus (TP), orthophosphate-phosphorus $\left(\mathrm{PO}_{4}{ }^{3-}-\mathrm{P}\right)$, and total nitrogen $(\mathrm{TN})$ were analyzed using a flow injection analyzer (FIA) (Tecator 5012, Foss Tecator, Sollentuna, Sweden) after oxidation with potassium peroxodisulphate. The water samples used for analysis of DOC and $\mathrm{PO}_{4}{ }^{3-}-\mathrm{P}$ were filtered through $0.45-\mu \mathrm{m}$ syringe filters (Millipore, Billerica, MA) without delay at the time of sampling. Distillable phenols were analyzed using a

Table 1. Description of Sampling Points at the Sawmill (See Also Fig. 1)

\begin{tabular}{|c|c|}
\hline Sampling point 1 & $\begin{array}{l}\text { Start of collection ditch for the part of the log yard that only stored Picea abies (L.) Karst (Norway } \\
\text { spruce) }\end{array}$ \\
\hline Sampling point 2 & Start of collection ditch for the part of the log yard that mainly stored Pinus sylvestris L. (Scots pine) \\
\hline Sampling point 3 & $200 \mathrm{~m}$ downstream of location 1 in collection ditch \\
\hline Sampling point 4 & $200 \mathrm{~m}$ downstream of location 2 in collection ditch \\
\hline Sampling point 5 & Before the first storage pond, and just after mixing of water from location 3 and 4 \\
\hline Sampling point 6 & After the first storage pond, and just before the gravel bed \\
\hline Sampling point 7 & After the gravel bed \\
\hline Sampling point 8 & $\begin{array}{l}\text { In a culvert located } 400 \mathrm{~m} \text { downstream of the gravel bed, and just before mixing with water from } \\
\text { location } 9 \text {. Further runoff from other areas of the sawmill where no logs are stored is added to the } \\
\text { log yard runoff along the culvert before sampling point } 8\end{array}$ \\
\hline Sampling point 9 & Runoff from further other areas of the sawmill \\
\hline Sampling point 10 & Inlet to the two last storage ponds \\
\hline Sampling point 11 & Outlet into the receiving watercourse \\
\hline Sampling point 12 & Intake point for sprinkling water from the receiving watercourse \\
\hline
\end{tabular}


Table 2. Measurements of the Constructed Wetland with the Two Wetland Components (First and Second) Presented Separately and Combined

\begin{tabular}{lccccc}
\hline & $\begin{array}{c}\text { First } \\
\text { sedimen- }\end{array}$ & $\begin{array}{c}\text { First } \\
\text { wetland }\end{array}$ & $\begin{array}{c}\text { Second } \\
\text { sedimen- }\end{array}$ & \multicolumn{2}{c}{$\begin{array}{c}\text { Second } \\
\text { wetland }\end{array}$} \\
Measurements tation basin & filter & tation basin & filter & Total \\
\hline Length & $10 \mathrm{~m}$ & $34 \mathrm{~m}$ & $17 \mathrm{~m}$ & $49 \mathrm{~m}$ & $110 \mathrm{~m}$ \\
Width & $3 \mathrm{~m}$ & $2.5 \mathrm{~m}$ & $2.7 \mathrm{~m}$ & $2.1 \mathrm{~m}$ & - \\
Depth & $1.5 \mathrm{~m}$ & $0.5 \mathrm{~m}$ & $1.5 \mathrm{~m}$ & $0.4 \mathrm{~m}$ & - \\
Area & $30 \mathrm{~m}^{2}$ & $85 \mathrm{~m}^{2}$ & $46 \mathrm{~m}^{2}$ & $103 \mathrm{~m}^{2}$ & $263 \mathrm{~m}^{2}$ \\
Volume & $45 \mathrm{~m}^{3}$ & $43 \mathrm{~m}^{3}$ & $69 \mathrm{~m}^{3}$ & $41 \mathrm{~m}^{3}$ & $198 \mathrm{~m}^{3}$ \\
\hline
\end{tabular}

FIA (Tecator 5012, see above) after distillation with Kjeltec 1026 (Foss Tecator, Sollentuna, Sweden). Suspended solids (SS) were analyzed by filtration through a $0.2-\mu \mathrm{m}$ filter paper (Millipore), drying at $105^{\circ} \mathrm{C}$ and subsequent weighing. The $\mathrm{pH}$ was analyzed with a Mettler DL70 titrator (Mettler Instrumente AG, Greifensee, Schweiz).

Two-sample $t$-tests were performed to directly compare mean values in different sampling points. All statistical evaluations were performed using the Minitab 15 software package (Minitab, 2006).

\section{Construction of the wetland}

During autumn 2005, part of the log yard ditch between sampling points 1 and 3 (Fig. 1) was reconstructed into a surface-flow constructed wetland. The wetland was constructed according to a conceptual model described by Braskerud $(2002,2003)$ that has been shown to be very efficient for reduction of TP and SS despite very small wetland sizes. Two wetland cells, each consisting of a deeper part for sedimentation of relatively large particles and a shallow vegetated part for filtering and subsequent sedimentation of finer particles were retrofitted in series within the original ditch. The area that was possible to use for the constructed wetland was restricted in size by the asphalted log yard area in the north and a nonsprinkled area in the south where the sawmill operator stores logs temporarily before the sprinkling season. The dimension details of the constructed wetland are presented in Table 2 (see also Fig. 1). Direct runoff from the yard was prevented from entering the wetland, potentially bypassing the automatic flow-proportional samplers, by a low asphalt threshold along the southern side of the log yard adjacent to the wetland.

Sediment that had accumulated during several sprinkling seasons within the original ditch was removed before retrofitting of the newly designed wetland began. At least three randomly selected Typha latifolia L. (bulrush), Phragmites australis (Cav.) Steud. (common reed), and/or Carex spp. (sedge) macrophytes from a local source were planted per square meter. However, most of the replanted macrophytes did not remain firmly rooted. It followed that the vegetation cover in the wetland was not satisfactory during the sprinkling season in 2006. Nevertheless, T. latifolia recolonized the ditch by vegetative rhizomes from the sides during summer 2006, but the vegetation cover was not dense; only about one macrophyte per square meter.

In the middle of May 2007, the plant cover in the wetland was improved through planting of three $P$. australis plants per square meter. The macrophytes were taken from a nonwaterlogged location within the sawmill area, and the rhizomes and roots were washed to ensure that no alien soil material was imported into the wetland. The aquatic plants were tied to bricks and supported by wooden sticks and then placed with their rhizomes in the muddy bottom substrate of the wetland ditch. The bricks and the wooden sticks were used to support the plants and to prevent them from floating away with the streaming water. This strategy was successful, and the growth of the macrophytes was satisfactory thereafter. The plant cover in 2007 increased significantly compared to the previous year.

Table 3. Results for Log Yard Runoff Grab-Sampled in 2004 at 12 Sampling Points (1-12)

Along the Route of the Runoff from the Log Yard to the Receiving Watercourse (Sampling Point Locations Are Described in Table 1)

\begin{tabular}{|c|c|c|c|c|c|c|c|c|c|c|c|c|}
\hline & 1 & 2 & 3 & 4 & 5 & 6 & 7 & 8 & 9 & 10 & 11 & 12 \\
\hline \multicolumn{13}{|l|}{ TOC } \\
\hline Mean & 114.3 & 80.5 & 88.4 & 78.5 & 77.5 & 75.7 & 59.7 & 48.2 & 47.4 & 43.0 & 65.0 & 26.7 \\
\hline Stdev & 20.91 & 12.71 & 12.72 & 11.49 & 10.17 & 10.67 & 13.83 & 6.08 & 15.86 & 14.35 & 39.30 & 31.85 \\
\hline$n$ & 7 & 7 & 7 & 6 & 7 & 7 & 7 & 6 & 7 & 7 & 7 & 7 \\
\hline \multicolumn{13}{|l|}{$\mathrm{TP}$} \\
\hline Mean & 1.30 & 1.22 & 1.01 & 0.98 & 1.06 & 1.02 & 0.90 & 0.79 & 0.35 & 0.54 & 0.90 & 0.05 \\
\hline Stdev & 0.281 & 0.201 & 0.170 & 0.072 & 0.214 & 0.148 & 0.288 & 0.147 & 0.171 & 0.232 & 0.325 & 0.031 \\
\hline$n$ & 7 & 7 & 7 & 6 & 7 & 7 & 7 & 7 & 7 & 7 & 7 & 6 \\
\hline \multicolumn{13}{|l|}{$\mathrm{pH}$} \\
\hline Mean & 7.2 & 6.9 & 6.9 & 7.0 & 6.8 & 6.8 & 7.0 & 7.7 & 7.6 & 7.6 & 7.4 & 8.0 \\
\hline Stdev & 0.35 & 0.29 & 0.23 & 0.25 & 0.28 & 0.15 & 0.21 & 0.59 & 0.46 & 0.27 & 0.40 & 1.03 \\
\hline$n$ & 7 & 7 & 7 & 6 & 7 & 7 & 7 & 6 & 6 & 7 & 7 & 6 \\
\hline \multicolumn{13}{|l|}{ Phenols } \\
\hline Mean & 0.01 & 0.20 & 0.02 & 0.03 & 0.04 & 0.06 & 0.02 & 0.02 & 0.01 & 0.02 & 0.02 & 0.02 \\
\hline$n$ & 1 & 1 & 1 & 1 & 1 & 1 & 1 & 1 & 1 & 1 & 1 & 1 \\
\hline
\end{tabular}

Concentrations in $\mathrm{mg} \mathrm{L}^{-1}$

TOC, total organic carbon; TP, total phosphorus; phenols, total distillable phenols; Stdev, standard deviation; $n$, number of samples. 


\section{Results and Discussion}

Runoff water treatment before construction of the wetland

T3 Results from the grab samples taken in 2004 (Table 3) show that the log yard runoff at the site compares well with runoff from other log yards storing $P$. abies logs. The TOC, TP, and TN concentrations are usually approximately between 75 and 200, 0.8 and 3.9 , and 0.8 and $2.7 \mathrm{mg} \mathrm{L}^{-1}$, respectively, and $\mathrm{pH}$ is usually around 6.7-7.2 (Jonsson et al., 2004, 2006; Hedmark and Jonsson, 2008). These values are generally much lower than what can be found in, for example, waste water and landfill leachate, and similar to heavily polluted storm water (Scholz, 2006). The results show that the existing abatement system (i.e., three storage ponds and a nonmaintained vertical subsurface gravel filter) did not reduce the concentrations of TOC and TP in the runoff. The inflow (sampling point 5) and outflow (sampling point 6) of the first storage pond had very similar concentrations of TOC and TP, respectively. The inflow (sampling point 10) and the outflow (sampling point 11) of the last two storage ponds show a significant $(p<0.05)$ increase in concentrations of TP and a large but not statistically significant increase of TOC, respectively. This could be explained by leaching of carbon compounds and nutrients from degradation of organic matter that had previously settled in the storage ponds. It could also indicate that the particles in the log yard runoff take too long time to settle. The inflow (Fig. 1; sampling point 6) and outflow (Fig. 1; sampling point 7) water samples of the vertical subsurface flow gravel filter showed a significant $(p<0.05)$ reduction of TOC and a large but not statistically significant reduction of TP, respectively. It is unlikely that the reductions in concentrations can be attributed to the gravel filter, because it was clogged, and virtually all runoff bypassed the submerged filter without any noticeable infiltration. Due to accessibility problems, the samples had to be taken 10-15 $\mathrm{m}$ downstream of the filter, after passage through a seminatural wetland vegetated by T. latifolia. The treatment effect was therefore assumed to be attributed to the wetland.

The concentrations of TOC and TP reduced significantly along the flow path of the runoff from the log yard to the final storage ponds. The reduction from sampling point 7 to sampling point 10 (Fig. 1) could be due to inflow of storm water from areas of the sawmill where no logs were stored. No such addition of storm water was possible between sampling points 1 and 2 (directly where the runoff leaves the asphalted log yard) and sampling point 7 , and a significant $(p<0.05)$ reduction of TOC and TP could be seen here as well, further strengthening the hypothesis that biochemical degradation and mechanical filtration through the existing macrophytes had a positive effect and reduced the level of pollution in the runoff.

The $\mathrm{pH}$ was lower in the runoff water than in the sprinkling water taken from the receiving watercourse (Fig. 1; sampling point 12). The $\mathrm{pH}$ values were, however, approximately neutral, and of a level that is normal for natural regional watercourses, and the values increased along the flow path of the runoff. Only one analysis of distillable phenols was made per sampling point in 2004 . The concentrations are presented in Table 3 mainly to give information about the level of phenols in the runoff in this study.

The number of sampling points was reduced in 2005, and the research focused on the edge of the log yard (sampling

Table 4. Results for Log Yard Runoff Sampled 2005 at Six Sampling Points Along the Flow of the Runoff from Log Yard to Recipient (Sampling Point Locations Are Described in Table 1)

\begin{tabular}{|c|c|c|c|c|c|c|}
\hline & 1 & 2 & 3 & 4 & 11 & 12 \\
\hline \multicolumn{7}{|l|}{ TOC } \\
\hline Mean & 114.2 & 98.7 & 82.6 & 79.9 & 52.2 & 11.6 \\
\hline Stdev & 34.65 & 28.65 & 21.60 & 11.49 & 6.70 & 1.49 \\
\hline$n$ & 8 & 8 & 8 & 8 & 8 & 8 \\
\hline \multicolumn{7}{|l|}{$\mathrm{TP}$} \\
\hline Mean & 2.09 & 1.91 & 1.87 & 1.62 & 1.10 & 0.06 \\
\hline Stdev & 0.783 & 1.040 & 0.904 & 0.986 & 0.420 & 0.013 \\
\hline$n$ & 8 & 8 & 8 & 8 & 8 & 8 \\
\hline \multicolumn{7}{|l|}{$\mathrm{pH}$} \\
\hline Mean & 7.2 & 7.1 & 7.3 & 7.2 & 7.5 & 7.8 \\
\hline Stdev & 0.19 & 0.23 & 0.20 & 0.18 & 0.10 & 0.07 \\
\hline$n$ & 8 & 8 & 8 & 8 & 8 & 8 \\
\hline \multicolumn{7}{|l|}{ SS } \\
\hline Mean & 108 & 70 & 122 & 114 & 116 & 37 \\
\hline Stdev & 73.4 & 29.5 & 50.7 & 36.3 & 32.5 & 9.5 \\
\hline$n$ & 8 & 8 & 8 & 8 & 8 & 8 \\
\hline \multicolumn{7}{|l|}{$\mathrm{TN}$} \\
\hline Mean & 0.81 & $\mathrm{n} / \mathrm{a}$ & $\mathrm{n} / \mathrm{a}$ & $\mathrm{n} / \mathrm{a}$ & 0.85 & $\mathrm{n} / \mathrm{a}$ \\
\hline Stdev & 0.160 & $\mathrm{n} / \mathrm{a}$ & $\mathrm{n} / \mathrm{a}$ & $\mathrm{n} / \mathrm{a}$ & 0.373 & $\mathrm{n} / \mathrm{a}$ \\
\hline$n$ & 2 & 0 & 0 & 0 & 2 & 0 \\
\hline \multicolumn{7}{|l|}{ Phenols } \\
\hline Mean & 0.05 & $\mathrm{n} / \mathrm{a}$ & $\mathrm{n} / \mathrm{a}$ & $\mathrm{n} / \mathrm{a}$ & 0.06 & $\mathrm{n} / \mathrm{a}$ \\
\hline Stdev & 0.030 & $\mathrm{n} / \mathrm{a}$ & $\mathrm{n} / \mathrm{a}$ & $\mathrm{n} / \mathrm{a}$ & 0.054 & $\mathrm{n} / \mathrm{a}$ \\
\hline$n$ & 2 & 0 & 0 & 0 & 2 & 0 \\
\hline
\end{tabular}

All samples are grab samples. Concentrations in $\mathrm{mg} \mathrm{L}^{-1}$. 
points 1 and 2), the next sampling points approximately $200 \mathrm{~m}$ further downstream (sampling points 3 and 4), the emissions to the recipient (sampling point 11) and the water used for sprinkling (sampling point 12). The parameters SS and TN were added to the sampling regime. The section of the flow path between sampling points 1 and 3, and between 2 and 4 (except where culverted) mainly consisted of ditches naturally vegetated by T. latifolia, P. australis, and Carex spp.

T4 The results for $\mathbf{2 0 0 5}$ (Table 4) confirmed that a considerable reduction of TOC and TP was achieved between sampling points 1 and 3 as well as between 2 and 4, respectively. The increase in SS was assumed to be caused by resuspension of previously settled sediments between the sampling points. Only a couple of samples were analyzed for TN because previous studies (Jonsson et al., 2006) had shown that the level of TN is generally low in runoff from log yards storing Picea abies and Pinus sylvestris. The results for TN and distillable phenols are presented in Table 4 to indicate the levels in the runoff of this study.

The positive results from the upper part of the flow path led to the decision to try to improve the treatment effect of the ditch between sampling points 1 and 3 by introducing deep zones for sedimentation and increasing the vegetation cover in shallow filtration zones (see above). The construction of a very shallow overflow area to increase the aeration of the water, or even the addition of mechanical aeration, was considered, but rejected because of the increased costs this would impose on the sawmill operator. One of the purposes of the project was to find a treatment solution that would be cost- effective and cause the least imposition possible on the normal operation of the sawmill.

\section{Runoff water treatment after construction of the wetland}

The same sampling points were investigated in 2006 as 2005, and the sampling points at the inlet and the outlet of the constructed wetland were also included in the sampling regime as automatic flow-proportional samples. The concentrations of TOC reduced significantly $(p<0.05)$ from sampling point 1 to sampling point 3 , but the decrease of TP was not statistically significant. There was a small decrease in TP from sampling point 2 to 4 , but TOC increased slightly between these sampling points (Table 5). A slight decrease in concentrations of TOC, TP, and SS in the wetland (inlet PT1 outlet PT2) was also recorded. However, the decrease was not statistically significant. Considering that the vegetation cover was not satisfactory in the wetland, it was assumed that the low treatment efficiency might be improved by increasing the plant cover before the next sprinkling season.

A few samples were analyzed for $\mathrm{TN}$ and the results are presented in Table 5 to confirm that the concentrations in runoff from $\log$ yards storing $P$. abies and $P$. sylvestris are generally rather low. There was a small decrease in TN over the wetland, but there was no clear trend of decrease along the flow path from log yard to recipient.

The most important finding of the results from 2006 was that the concentrations of TP were much higher than in pre-

Table 5. Results for log Yard Runoff Sampled 2006 at Six Sampling Points Along the Flow of the Runoff from Log Yard to Recipient (Sampling Point Locations Are Described in Table 1) and Before (PT1) and After (PT2) the Constructed Surface Flow Wetland

\begin{tabular}{|c|c|c|c|c|c|c|c|c|}
\hline & 1 & 2 & 3 & 4 & 11 & 12 & PT1 & PT2 \\
\hline \multicolumn{9}{|l|}{ TOC } \\
\hline Mean & 138.0 & 99.8 & 103.4 & 109.1 & 75.8 & 15.3 & 83.8 & 79.9 \\
\hline Stdev & 13.35 & 10.71 & 25.27 & 10.35 & 17.95 & 1.69 & 19.33 & 21.27 \\
\hline$n$ & 7 & 8 & 8 & 8 & 9 & 9 & 6 & 6 \\
\hline \multicolumn{9}{|l|}{$\mathrm{TP}$} \\
\hline Mean & 9.2 & 6.7 & 7.3 & 6.2 & 5.9 & 0.1 & 9.3 & 8.4 \\
\hline Stdev & 1.88 & 2.27 & 3.22 & 2.27 & 2.53 & 0.03 & 2.43 & 2.98 \\
\hline$n$ & 7 & 8 & 8 & 8 & 9 & 9 & 6 & 6 \\
\hline \multicolumn{9}{|l|}{$\mathrm{pH}$} \\
\hline Mean & 7.7 & 7.6 & 7.8 & 7.8 & 8.0 & 9.0 & 8.7 & 8.5 \\
\hline Stdev & 0.43 & 0.41 & 0.36 & 0.33 & 0.46 & 0.38 & 0.33 & 0.31 \\
\hline$n$ & 7 & 8 & 8 & 8 & 9 & 9 & 6 & 6 \\
\hline \multicolumn{9}{|l|}{ SS } \\
\hline Mean & $\mathrm{n} / \mathrm{a}$ & $\mathrm{n} / \mathrm{a}$ & $\mathrm{n} / \mathrm{a}$ & $\mathrm{n} / \mathrm{a}$ & $\mathrm{n} / \mathrm{a}$ & $\mathrm{n} / \mathrm{a}$ & 94 & 94 \\
\hline Stdev & $\mathrm{n} / \mathrm{a}$ & $\mathrm{n} / \mathrm{a}$ & $\mathrm{n} / \mathrm{a}$ & $\mathrm{n} / \mathrm{a}$ & $\mathrm{n} / \mathrm{a}$ & $\mathrm{n} / \mathrm{a}$ & 43.7 & 65.9 \\
\hline$n$ & $\mathrm{n} / \mathrm{a}$ & $\mathrm{n} / \mathrm{a}$ & $\mathrm{n} / \mathrm{a}$ & $\mathrm{n} / \mathrm{a}$ & $\mathrm{n} / \mathrm{a}$ & $\mathrm{n} / \mathrm{a}$ & 6 & 6 \\
\hline \multicolumn{9}{|l|}{$\mathrm{TN}$} \\
\hline Mean & 1.49 & 1.64 & 1.51 & 1.48 & 1.25 & 0.64 & 1.62 & 1.49 \\
\hline Stdev & 0.506 & 0.368 & 0.437 & 0.504 & 0.295 & 0.108 & 0.184 & 0.276 \\
\hline$n$ & 3 & 3 & 3 & 3 & 3 & 3 & 2 & 2 \\
\hline \multicolumn{9}{|c|}{ Phenols } \\
\hline Mean & $\mathrm{n} / \mathrm{a}$ & $\mathrm{n} / \mathrm{a}$ & $\mathrm{n} / \mathrm{a}$ & $\mathrm{n} / \mathrm{a}$ & $\mathrm{n} / \mathrm{a}$ & $\mathrm{n} / \mathrm{a}$ & 0.02 & 0.01 \\
\hline Stdev & $\mathrm{n} / \mathrm{a}$ & $\mathrm{n} / \mathrm{a}$ & $n / a$ & $\mathrm{n} / \mathrm{a}$ & $n / a$ & $\mathrm{n} / \mathrm{a}$ & 0.006 & 0.007 \\
\hline$n$ & $\mathrm{n} / \mathrm{a}$ & $\mathrm{n} / \mathrm{a}$ & $\mathrm{n} / \mathrm{a}$ & $\mathrm{n} / \mathrm{a}$ & $\mathrm{n} / \mathrm{a}$ & $\mathrm{n} / \mathrm{a}$ & 6 & 5 \\
\hline
\end{tabular}

All samples taken at sampling point 1, 2, 3, 4, 11, and 12 are grab samples. All samples taken at sampling points PT1 and PT2 are flow proportional composite samples. Concentrations in $\mathrm{mg} \mathrm{L}^{-1}$. 
vious years; that is, up to $9 \mathrm{mg} \mathrm{L}^{-1}$ compared to $1-2 \mathrm{mg} \mathrm{L}^{-1}$ for the other investigated years. The increase could not be attributed to disturbances from the construction of the wetland, because the concentrations were elevated also upstream of the wetland (sampling point 1 ) and along the flow path that was not affected by the wetland construction (sampling points 2 and 4). The increase was most likely caused by the storage of windthrown logs that had been left in the forest since the hurricane in January 2005 (see above), and these results are discussed below.

The results from 2007 show that the TP concentrations had reduced to normal levels again, probably because no more windthrown logs from the hurricane in 2005 were stored on the log yard (Table 6). During 2007, some of the samples were filtered at the time of sampling to make it possible to analyze the concentrations of DOC and $\mathrm{PO}_{4}{ }^{3-}-\mathrm{P}$. The results showed that as little as around 19 and $35 \%$ of the TOC and the TP, respectively, were present in dissolved form in the runoff. This should increase the possibility of a high treatment effect for log yard runoff in constructed wetlands.

The planting of P. australis that was performed in May 2007 led to an increase in plant cover during summer 2007. Toward the end of the sprinkling season, when the plant cover was at its maximum, the sampling frequency of the inflow and out- flow of the wetland was increased. From 23 August to 4 October, 25 composite samples were taken from sampling points PT1 and PT2. The number of samples increased the statistical confidence in the results from the wetland treatment.

Despite the increased plant cover, no improved treatment effect could be measured over the wetland. There was no reduction in concentrations of TOC, TP, SS, or TN. This was an unexpected result considering the reduction in concentrations of TOC and TP that had been measured in the ditches along the flow path of the runoff during previous years. Probable explanations for the lack of treatment effect are the high hydraulic loading rate and the low DOC in the runoff. The hydraulic loading rate during 2007 was $0.68 \mathrm{~m}_{\text {day }}{ }^{-1}$, the mean flow was $7.4 \mathrm{~m}^{3} \mathrm{~h}^{-1}$ and the retention time for the runoff in the wetland was as low as $27 \mathrm{~h}$.

The DOC was occasionally measured with a portable oxygen meter in different parts and at different depths of the wetland. For example, in July 2007, the measured oxygen concentrations were as low as between 0.4 and $1.7 \mathrm{mg} / \mathrm{L}$ (3.7$17.3 \%$ ) at a mean temperature of approximately $15^{\circ} \mathrm{C}$. It follows that oxygenation due to the sprinkling process and flow through the wetland was relatively ineffective.

The hydraulic loading rate was, however, expected to be acceptable, because constructed wetland studies by Braskerud

Table 6. Results for log Yard Runoff Sampled 2007 at Four Sampling Points Along the Flow of the Runoff from Log Yard to Recipient (Sampling Point Locations Are Described in Table 1) and Before (PT1) and After (PT2) the Constructed Surface Flow Wetland

\begin{tabular}{|c|c|c|c|c|c|c|}
\hline & 1 & 2 & 11 & 12 & PT1 & PT2 \\
\hline \multicolumn{7}{|l|}{ TOC } \\
\hline Mean & 74.7 & 82.0 & 62.5 & 29.6 & 70.4 & 68.1 \\
\hline Stdev & 17.09 & 16.21 & 7.55 & 2.28 & 17.35 & 19.75 \\
\hline$n$ & 8 & 8 & 8 & 8 & 32 & 32 \\
\hline \multicolumn{7}{|l|}{ DOC } \\
\hline Mean & 13.4 & 14.2 & 12.8 & 5.8 & 13.9 & 13.9 \\
\hline Stdev & 2.81 & 3.10 & 1.16 & 1.29 & 2.26 & 3.16 \\
\hline$n$ & 5 & 5 & 5 & 4 & 30 & 30 \\
\hline \multicolumn{7}{|l|}{$\mathrm{TP}$} \\
\hline Mean & 0.80 & 0.97 & 0.77 & 0.06 & 0.99 & 1.00 \\
\hline Stdev & 0.399 & 0.346 & 0.240 & 0.052 & 0.414 & 0.427 \\
\hline$n$ & 8 & 8 & 8 & 8 & 32 & 32 \\
\hline \multicolumn{7}{|c|}{$\mathrm{PO}_{4}{ }^{3-}-\mathrm{P}$} \\
\hline Mean & 0.28 & 0.38 & 0.25 & 0.01 & 0.18 & 0.19 \\
\hline Stdev & 0.251 & 0.396 & 0.222 & 0.012 & 0.139 & 0.169 \\
\hline$n$ & 7 & 7 & 7 & 7 & 31 & 31 \\
\hline \multicolumn{7}{|l|}{$\mathrm{pH}$} \\
\hline Mean & 6.8 & 6.7 & 7.2 & 7.9 & 7.2 & 7.3 \\
\hline Stdev & 0.18 & 0.28 & 0.28 & 0.41 & 0.36 & 0.36 \\
\hline$n$ & 8 & 8 & 8 & 8 & 32 & 32 \\
\hline \multicolumn{7}{|l|}{ SS } \\
\hline Mean & $\mathrm{n} / \mathrm{a}$ & $\mathrm{n} / \mathrm{a}$ & $\mathrm{n} / \mathrm{a}$ & $\mathrm{n} / \mathrm{a}$ & 55 & 57 \\
\hline Stdev & $\mathrm{n} / \mathrm{a}$ & $\mathrm{n} / \mathrm{a}$ & $\mathrm{n} / \mathrm{a}$ & $\mathrm{n} / \mathrm{a}$ & 22.1 & 12.5 \\
\hline$n$ & $\mathrm{n} / \mathrm{a}$ & $\mathrm{n} / \mathrm{a}$ & $\mathrm{n} / \mathrm{a}$ & $\mathrm{n} / \mathrm{a}$ & 32 & 32 \\
\hline \multicolumn{7}{|l|}{$\mathrm{TN}$} \\
\hline Mean & 0.72 & 0.89 & 0.73 & 0.75 & 1.18 & 1.33 \\
\hline Stdev & 0.091 & 0.340 & 0.112 & 0.004 & 0.350 & 0.485 \\
\hline$n$ & 2 & 2 & 2 & 2 & 3 & 3 \\
\hline
\end{tabular}

All samples taken at sampling point 1, 2, 11, and 12 are grab samples. All samples taken at sampling points PT1 and PT2 are flow proportional composite samples. Concentrations in $\mathrm{mg} \mathrm{L}^{-1}$.

$\mathrm{PO}_{4}{ }^{3-}-\mathrm{P}$, ortho-phosphate-phosphorus. 
Table 7. Results for Log Yard Runoff Sampled Between the Sprinkling Seasons 2006 and 2007 in Sampling Point PT1, Before the Constructed Surface Flow Wetland, nd PT2, Ater the Wtland

\begin{tabular}{lcc}
\hline & $P T 1$ & $P T 2$ \\
\hline TOC & & \\
Mean & 78.2 & 75.7 \\
Stdev & 32.70 & 39.81 \\
$n$ & 3 & 3 \\
TP & & \\
Mean & 0.95 & 0.81 \\
Stdev & 0.372 & 0.459 \\
$n$ & 3 & 3 \\
PH & & \\
Mean & 6.8 & 7.0 \\
Stdev & 0.27 & 0.46 \\
$n$ & 3 & 3 \\
\hline
\end{tabular}

Samples are flow proportional composite samples. Concentrations in $\mathrm{mg} \mathrm{L}^{-1}$.

$(2002,2003)$ have shown good treatment effects for TP and SS with hydraulic loading rates as high as 0.7 to $2.0 \mathrm{~m} \mathrm{day}^{-1}$. The constructed wetland in this study was constructed in a similar way as in the studies by Braskerud $(2002,2003)$, and the water streams from the different studies (log yard runoff and runoff from agricultural catchments, respectively) had roughly the same characteristics regarding a high content of TP and SS. Nevertheless, the log yard runoff was apparently so different that the same wetland design was not appropriate. Despite physical oxygenation (sprinkling and flow within wetland), it is likely that the high content of organic matter in the log yard runoff led to a very low oxygen content in the water due to aerobic biodegradation processes, and this most likely led to reduced treatment efficiency. However, an abundance of nonlabile carbon compounds was likely to be responsible for only a modest removal of TOC due to its low biodegradability; examples have been reviewed by Hedmark and Scholz (2008). It is also possible that the particles that are present in $\log$ yard runoff do not settle as efficiently as particles in the runoff from agricultural fields.

\section{Function of the wetland outside the sprinkling season}

The results in Table 7 show that the mean concentrations of TOC and the $\mathrm{pH}$ of the runoff were roughly the same between the sprinkling seasons (October 2006-early May 2007) as during the sprinkling seasons 2006 and 2007 (May-end of September). The mean concentrations of TP during the sprinkling season 2006 were unusually high (see below), but the values between the sprinkling seasons 2006 and 2007 were similar to the values during the sprinkling season 2007. The findings for concentrations and flow showed that the wetland did not function as a source of pollutants during the cold season. The flow of water was considerably lower between the sprinkling seasons $\left(2900 \mathrm{~m}^{3}\right)$ than during them $\left(27,500 \mathrm{~m}^{3}\right.$ in 2007), and consequently, the transport of TOC and TP was much smaller. Between the seasons, the load on the wetland was $262 \mathrm{~kg}$ TOC and $3 \mathrm{~kg}$ TP. During the sprinkling season 2007, the corresponding load was $2120 \mathrm{~kg}$ TOC and $33 \mathrm{~kg}$ TP. The treatment efficiency generally did not increase, although
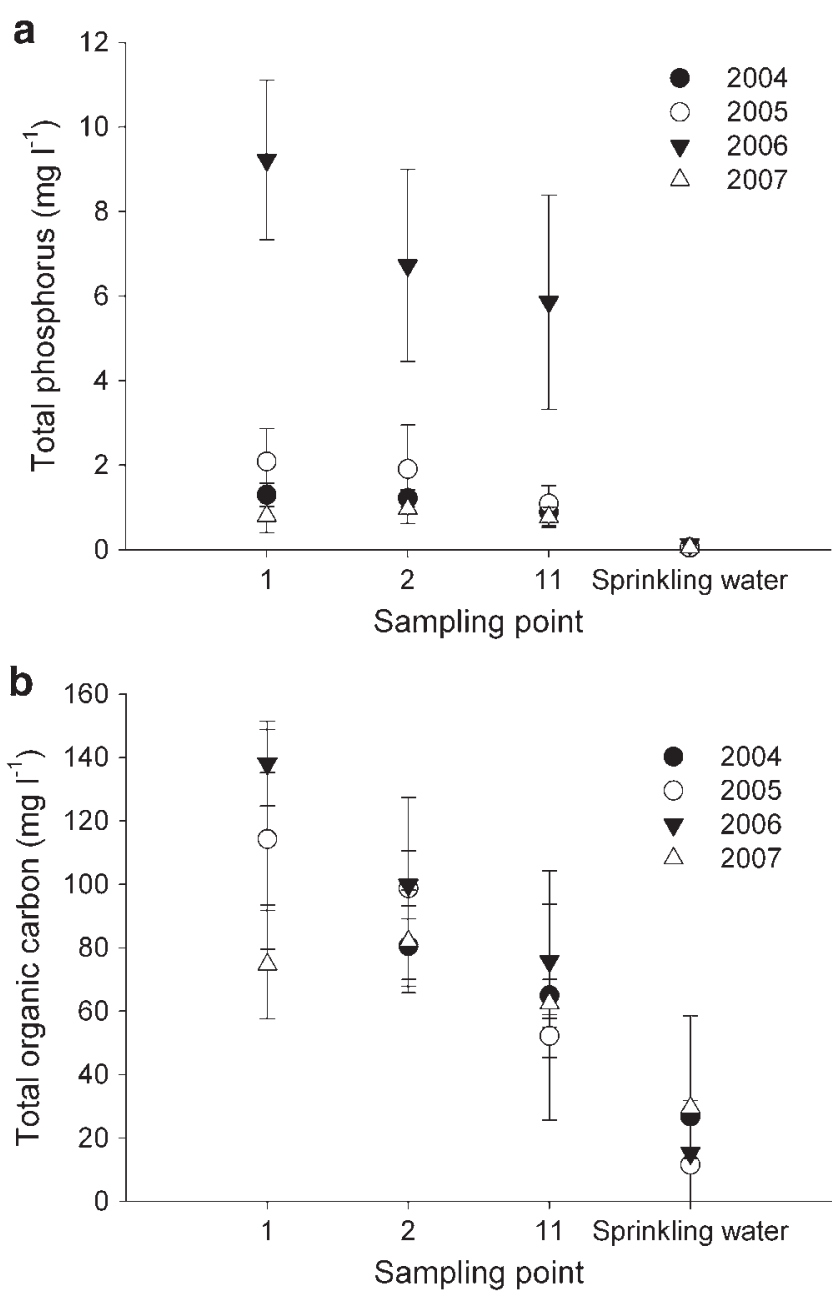

FIG. 2. Concentration of (a) total phosphorus and (b) total organic carbon $(\mathrm{mg} / \mathrm{L})$ in log yard runoff from sampling points $1,2,11$, and in the incoming water before sprinkling during the sprinkling seasons 2004-2007. All samples are grab samples. $n=7$ in 2004; $n=8$ for 2005-2007.

the hydraulic loading rate was much smaller and the retention time consequently much higher, but this can at least partially be explained by the cold climate from October to May and the lack of oxygenation of the relatively still-standing water.

\section{Runoff characteristics for aged windthrown logs}

The most important finding in 2006 was that the concentration of TP in the runoff was much higher than during previous years. The increase was observed for all sampling points except for the incoming sprinkling water, showing that the difference was not due to changes in the incoming sprinkling water. That the incoming sprinkling water showed normal levels also confirmed that the increase was not caused by contaminated sampling bottles or an error during analysis.

The storage of sprinkled logs in the yard considerably increased after the hurricane to allow for processing of more windthrown logs before they became too damaged by insects or fungi. The height of the piles was increased from approximately $3 \mathrm{~m}$ to roughly between 4 and $5 \mathrm{~m}$, and up to $45,000 \mathrm{~m}^{3}$ of sprinkled logs were stored. This is a considerable 
increase compared to the normally permitted $24,000 \mathrm{~m}^{3}$. This increase of storage volume is, however, not sufficient to explain the high TP concentration increase during 2006.

F2 Figure 2a and b show the TP and TOC concentrations, respectively, in the runoff water where it runs off the log yard into the upper end of the collection ditches (sampling points 1 and 2) in comparison to the sprinkling water (sampling point 12) and the concentration in the water that reaches the recipient (sampling point 11). In 2007, the concentrations were back to normal levels, as recorded in previous years (Fig. 2a). Other parameters such as TOC did not show any clear increase (Fig. 2b).

A similar increase in concentration of TP when aged logs were stored was noticed at a sawmill in Heby (Västmanland, Sweden) (Hedmark et al., 2009) where the authors were investigating the treatment efficiency of soil infiltration of log yard runoff. At that sawmill there was also a significant increase in TOC concentration in the runoff. It is probable that the increase during 2006 can be explained by storage and sprinkling of logs that were windthrown during the hurricane in January 2005. Logs that are left in the forest for a relatively long period of time after felling are more affected by biological decay, and a larger proportion of TP is subsequently released from the logs during sprinkling on the log yard (Feist et al., 1971). The content of phosphorus in the stem wood of $P$. abies is between 9.2 and $47.0 \mathrm{mg} \mathrm{kg}^{-1}$ (Barrelet et al., 2006), and it is probable that a larger amount of TP will be released from aged logs that have started to degrade compared to logs that are fresher during sprinkling on the log yard.

The concentration of phosphorus has been found to increase in stem wood and inner bark toward the youngest tissues, from the pith (located in the center of the stem) of Pinus sylvestris to the youngest annual rings (Helmisaari and Siltala, 1989). If this is also the case for Picea abies, it could explain why the concentration of TP in the runoff increased when aged logs were stored on the log yards. Trees that have aged after felling usually have lost more of the outer bark than freshly felled trees, and it is possible that the leaching of phosphorus is greater when water comes in direct contact with the inner bark.

The increased concentration of phosphorus in runoff from aged logs has important consequences for the future storage requirements for logs that are windthrown. With increasing global warming, it is expected that extreme weather conditions will become more common, and countries with a lot of forest should prepare for storing windthrown logs in a way that reduces the impact of phosphorus on receiving watercourses.

\section{Conclusions and Recommendations for Further Research}

The results from other studies and the characteristics of the $\log$ yard runoff in this study indicate that small-scale wetland treatment should theoretically be possible. However, the results from this study did not support this theory. It is likely that the hydraulic loading rate for this wetland case study was too high, and that the concentration of oxygen in the runoff was too low for the biochemical processes in the wetland to reduce the concentrations of TP, TOC, and SS. Sampling results between autumn 2006 and spring 2007 indicated that contaminants do not leach out of the constructed wetland between the sprinkling seasons. Results from the studies in Boxholm and Heby showed that storage of aged windthrown logs led to a higher content of total phosphorus in the runoff. This is an important finding that should influence the location and design of storage sites for logs that will be windthrown during future storms.

The lack of effective treatment by the wetland is an important result for wetland designers. The experiences gained in this study are useful for the design and operation of more efficient wetlands treating log yard runoff in the future. For example, it should be advantageous to increase the wetland area and the density of planting. This would lead to an increase of the residence time and a decrease of the hydraulic loading rate. Moreover, a higher planting density would also result in higher sedimentation rates. Additional measures to achieve adequate treatment may include physical oxygenation via mechanical stirring or by conveyance of the runoff over shallow weirs, through permeable thresholds or along shallow swales. Pretreatment via mechanical filtration or posttreatment via a filter containing aggregates for enhanced phosphorus adsorption (e.g., iron ochre) should also help in improving the overall treatment efficiency.

\section{Acknowledgments}

The authors thank Tommy Halldin, Dan Fritz, and Kjell Carlsson (Rörvik Timber Boxholm AB) for financial support and help with constructing the wetland. Additional funding to support the research work was received from the Karl Eric Önnesjö's Foundation for Scientific Research and Development. Åsa Sjöblom, Fredric Carlsson, David Gilljam, Christian Karlsson, and Charlotte Uddén helped with planting and measuring the constructed wetland. Karin Tonderski provided valuable scientific advice.

\section{Author Disclosure Statement}

No competing financial interests exist.

\section{References}

Alexandersson, H., Karlström, C., and Larsson-McCann, S. (1991). Temperature and Precipitation in Sweden 1961-90. Reference values. SMHI 81 (in Swedish).

Barrelet, T., Ulrich, A., Rennenberg, H., and Krähenbühl, U. (2006). Seasonal profiles of sulphur, phosphorus, and potassium in Norway spruce wood. Plant Biol. 8, 462.

Björheden, R. (2007). Possible effects of the hurricane Gudrun on the regional Swedish forest energy supply. Biom. Bioeng. 31, 617.

Brandt, M., Jutman, T., and Alexandersson, H. (1994). The Water Balance of Sweden. Yearly Precipitation, Evaporation and Runoff Means 1961-1990. SMHI Hydrologi 49 (in Swedish).

Braskerud, B.C. (2002). Factor affecting phosphorus retention in small constructed wetlands treating agricultural non-point source pollution. Ecol. Eng. 19, 41.

Braskerud, B.C. (2003). Clay particle retention in small constructed wetlands. Water Res. 37, 3793.

DeHoop, C.F., Einsel, D.A., Ro, K.S., Chen, S., Gibson, M.D., and Grozdits, G.A. (1998). Storm water runoff quality of a Louisiana log storage and handling facility. J. Environ. Sci. Health 33, 165.

Feist, W.C., Springer, E.L., and Hajny, G.J. (1971). Viability of parenchyma cells in stored green wood. TAPPI 54, 1295. 
Hedmark, A., and Jonsson, M. (2008). Treatment of log yard runoff in a couch grass infiltration wetland in Sweden. Int. J. Environ. Stud. 65, 273.

Hedmark, Å., and Scholz, M. (2008). Review of environmental effects and treatment of runoff from storage and handling of wood. Biores. Tech. 99, 5997.

Hedmark, Å., Zhang, L., Scholz, M., Aronsson, P., and Elowson, T. (2009). Self-organizing map analysis of planted soil infiltration systems for treatment of log yard runoff. Forensic Sci. $55,183$.

Helmisaari, H.-S., and Siltala, T. (1989). Variation in nutrient concentrations of Pinus sylvestris stems. Scand J. Forensic Res. 4, 443.

Hildén, L., Zhang, J., Persson, E., Johansson, G., and Brändström, J. (2006). Distribution and characterisation of discolouring substances in Norway spruce (Picea abies L. Karst.) pulp wood stored under water sprinkling. Holzforschung 60, 93.

Jonsson, M. (2004). Wet storage of Round Wood. PhD thesis. Acta Universitatis Agriculturae Sueciae, Silvestria, Vol. 319. Uppsala: Swedish University of Agricultural Sciences.

Jonsson, M., Dimitriou, I., Aronsson, P., and Elowson, T. (2004). Effects of soil type, irrigation volume and plant species on treatment of log yard runoff in lysimeters. Water Res. 38, 3634.

Jonsson, M., Dimitriou, I., Aronsson, P., and Elowson, T. (2006). Treatment of log yard runoff by irrigation of grass and willows. Environ. Pollut. 139, 157.

Lee, B.-H., Scholz, M., and Horn A. (2006). Constructed wetlands for the treatment of concentrated stormwater runoff (Part A). Environ. Eng. Sci. 23, 191.

Lindelöw, Å., Risberg, B., and Sjödin, K. (1992). Attraction during flight of scylotids and other bark- and wood-dwelling beetles to volatiles from fresh and stored spruce wood. Can. J. Forest Res. 22, 224.

Liukko, K., and Elowson, T. (1995). Climate controlled sprinkling of saw timber. In Web Proceedings of the International Union of Forestry Research Organizations (IUFRO), XX World Congress, P3.07 Meeting, Tampere, Finland (6-12 August 1995), pp. 44-53. Corvallis, Oregon: Oregon State University (http://www .metla.fi/iufro/iufro95/index.htm).

Malan, F.S. (2004). Some notes on the effect of wet-storage on timber. South. Afr. Forestry J. 202, 77.
Masbough, A., Frankowski, K., Hall, K.J., and Duff, S.J.B. (2005). The effectiveness of constructed wetland for treatment of wood waste leachate. Ecol. Eng. 25, 552.

Minitab (2006). Minitab 15. Minitab Statistical Software, Release 15 for Windows. State College, PA: Minitab Inc., Pennsylvania State College.

Müller, M.M., Varama, M., Heinonen, J., and Hallaksela, A.-M. (2002). Influence of insects on the diversity of fungi in decaying spruce wood in managed and natural forests. Forest Ecol. Manage. 166, 165.

Orban, J.L., Kozak, R.A., Sidle, R.C., and Duff, S.J.B. (2002). Assessment of relative environmental risk from log yard runoff in British Columbia. Forestry Chr. 78, 146.

Scholz, M. (2006). Wetland Systems to Control Urban Runoff. Amsterdam: Elsevier.

Scholz, M., Sadowski, A.J., Harrington, R., and Carroll, P. (2007). Integrated constructed wetlands assessment and design for phosphate removal. Biosyst. Eng. 97, 415.

Skogsstyrelsen (2006). Stormen 2005-En Skoglig Analys (The storm 2005-A Forestry Analysis), Meddelande 1. Skogsstyrelsen, Jönköping, Sweden (in Swedish), 2006.

Tao, W., Hall, K.J., and Duff, S.J.B. (2006a). Treatment of wood waste leachate in surface flow mesocosm wetlands. Water Qual. Res. J. Can. 41, 325.

Tao, W., Hall, K.J., and Duff, S.J.B. (2006b). Performance evaluation and effects of hydraulic retention time and mass loading rate on treatment of wood waste leachate in surface-flow constructed wetlands. Ecol. Eng. 26, 252.

Webber, J., and Gibbs, J. (1996). Water Storage of Timber: Experience in Britain. Bulletin 117. London: Forestry Commission, Her Majesty's Stationary Office.

Wichmann, L., and Ravn, H.P. (2001). The spread of Ips typographus (L.) (Coleoptera, Scolytidae) attacks following heavy windthrow in Denmark, analyzed using GIS. Forest Ecol. Manage. 148,31 .

Woodhouse, C., and Duff, J.B.S. (2004). Treatment of log yard runoff in an aerobic trickling filter. Water Qual. Res. J. Can. 39, 230.

Zhang, Q.-H., and Schlyter, F. (2003). Redundancy, synergism, and active inhibitory range of non-host volatiles in reducing pheromone attraction in European spruce bark beetle Ips typographus. Oikos 101, 299. 